DOI: $10.19195 / 0524-4544.328 .8$

\author{
ŁUKASZ BASZAK \\ ORCID: 0000-0002-7895-7983 \\ Uniwersytet Wrocławski \\ lukasz.baszak@uwr.edu.pl
}

\title{
Prace legislacyjne nad ustawą o stosunku Państwa do Muzułmańskiego Związku Religijnego w Rzeczypospolitej Polskiej
}

\section{Wstęp}

W okresie międzywojennym państwo polskie zamieszkiwało wiele narodowości, co wpływało na strukturę wyznaniową. Według spisu powszechnego z 1921 roku Polskę zamieszkiwało 27,177 tys. osób. Polacy stanowili 69\% ogółu obywateli, Ukraińcy ponad 14\%, Żydzi 7,8\%, Białorusini 3,9\%, Niemcy 3,8\%, mniejsze grupy narodowościowe łącznie ponad 1\%. Natomiast 75\% ludności było wyznania rzymskokatolickiego (w tym 11,2\% obrządku greckokatolickiego), 10,5\% wyznania prawosławnego, 10,5\% wyznania mojżeszowego, 3,7\% wyznania ewangelicko-augsburskiego. Miało to istotny wpływ na stabilizację sytuacji wewnętrznej kraju. Polityka wyznaniowa związana więc była nieodłącznie z polityką narodowościową państwa. W związku z tym polityka rządu do mniejszości religijnych, w tym do muzułmanów, zależna była w dużej mierze od stosunku tych mniejszości do państwa polskiego ${ }^{1}$.

1 W. Wysoczański, M. Pietrzak, Prawo Kościołów i związków wyznaniowych nierzymskokatolickich $w$ Polsce, Warszawa 1997, s. 14; P.A. Leszczyński, Centralna administracja wyznaniowa w II RP. Ministerstwo Wyznań Religijnych i Oświecenia Publicznego, Warszawa 2006, s. 17. 
W okresie II Rzeczypospolitej stosunek państwa do związków wyznaniowych regulowały ustawy konstytucyjne z $1921^{2}$ i 1935 roku $^{3}$ wraz z aktami wykonawczymi. Prace nad uregulowaniem sytuacji prawnej związków mniejszości religijnych $\mathrm{w}$ tym okresie przebiegały $\mathrm{w}$ sposób zróżnicowany. Muzułmański Związek Religijny, mimo swojej niewielkiej liczebności, był jednym z niewielu związków mniejszości wyznaniowych, któremu udało się określić ustawowo stosunek do państwa.

Postanowienia Konstytucji z 17 marca 1921 roku$^{4}$ w zakresie stosunków wyznaniowych umieszczono w rozdziale V Konstytucji, który dotyczył praw i obowiązków obywatelskich. Regulowały one dwie zasadnicze kwestie: wolność sumienia i wyznania oraz sytuację prawną związków wyznaniowych. Artykuł 110 zapewniał obywatelom polskim należącym między innymi do mniejszości wyznaniowych równe prawa $\mathrm{z}$ innymi obywatelami do zakładania, nadzoru i zawiadywania swoim własnym kosztem zakładów religijnych i innych instytucji oraz prawo wykonywania w nich przepisów swej religii. Artykuły 111 i 112 dotyczyły wolności sumienia i wyznania ${ }^{5}$. Zgodnie z art. 111 wszystkim obywatelom przysługiwała wolność sumienia i wyznania, a żaden obywatel nie mógł być z powodu swego wyznania i przekonań religijnych ograniczony w prawach przysługujących innym obywatelom. Ponadto wszystkim mieszkańcom państwa przyznano prawo wolnego wyznawania swej wiary publicznie i prywatnie oraz wykonywania przepisów swej religii lub obrządku, o ile to nie sprzeciwia się porządkowi publicznemu ani obyczajności publicznej. Z kolei art. 112 stanowił, że wolności wyznania nie wolno było używać w sposób, który wskazywałby na naruszenie ustaw. Nikt nie mógł się uchylać od spełnienia obowiązków publicznych z powodu swych wierzeń religijnych oraz nikt nie mógł być zmuszony do udziału w czynnościach lub obrzędach religijnych, o ile nie podlegał władzy rodzicielskiej lub opiekuńczej. Natomiast art. 113-116 regulowały sytuację prawną związków wyznaniowych. Wzorem austriackim podzielono związki wyznaniowe

2 Dz.U. RP z 1921 r. Nr 44, poz. 267.

3 Dz.U. RP z 1935 r. Nr 30, poz. 277.

4 Kwestie związane ze stosunkiem państwa do związków wyznaniowych były przedmiotem sporów między lewicą a prawicą parlamentarną. Partie lewicowe, zwłaszcza PPS, domagały się uznania zasady rozdziału, laickości państwa, pozostawiając religię jako sprawę prywatną obywateli. Natomiast prawica z Narodową Demokracją na czele opowiadała się za modelem państwa wyznaniowego z nadaniem Kościołowi katolickiemu pozycji kościoła panującego. Działania partii prawicowych zostały oczywiście poparte przez Episkopat Polski. Artykuły dotyczące stosunków wyznaniowych w uchwalonej 17 marca 1921 roku konstytucji cechował kompromis między tymi dwiema koncepcjami; Ł. Baszak, Prace legislacyjne nad ustawa o stosunku Państwa do Karaimskiego Zwiazku Religijnego w Rzeczypospolitej Polskiej, „Folia Iuridica Universitatis Wratislaviensis" 4, 2015, nr 1, s. 131; zob. szerzej M. Pietrzak, Prawo wyznaniowe, Warszawa 2013, s. 112-123; A. Mezglewski, H. Misztal, P. Stanisz, Prawo wyznaniowe, Warszawa 2011, s. 27-28; J. Krukowski, Polskie prawo wyznaniowe, Warszawa 2008, s. 38.

5 Szerzej o pojęciu wolności sumienia i wyznania zob. W. Komarnicki, Polskie prawo polityczne (geneza i system), Warszawa 1922, s. 573-575.

Prawo 328, 2019

(C) for this edition by $\mathrm{CNS}$ 
na prawnie uznane i prawnie nieuznane ${ }^{6}$. Według art. 113 każdy związek religijny uznany przez państwo miał prawo do urządzania zbiorowych i publicznych nabożeństw, samodzielnego prowadzenia swoich spraw wewnętrznych, możność posiadania i nabywania majątku ruchomego i nieruchomego, zarządzania nim i rozporządzania, posiadania swoich fundacji i funduszów oraz zakładów dla celów dobroczynnych, naukowych i wyznaniowych. Wiązał się z tym obowiązek niepodejmowania takich działań, które stałyby w sprzeczności z ustawami. Oryginalnym rozwiązaniem był art. 114, który zagwarantował Kościołowi rzymskokatolickiemu naczelne stanowisko wśród równouprawnionych wyznań, rządzącego się własnymi prawami, którego pozycja prawna zostanie określona na podstawie układu ze Stolicą Apostolską ${ }^{7}$. Dzięki temu duchowieństwo katolickie miało większe dotacje $\mathrm{z}$ budżetu państwa oraz pierwszeństwo przed innymi wyznaniami na przykład podczas uroczystości państwowych ${ }^{8}$. Zgodnie z art. 115 stosunek państwa do kościołów mniejszości religijnych i innych prawnie uznanych związków religijnych miał być regulowany w drodze ustawowej po porozumieniu się z ich prawnymi reprezentantami. Kontynuacją tego artykułu był art. 116, który stanowił, że uznanie nowego lub dotychczas prawnie nieuznanego związku religijnego nie będzie odmówione tym wyznaniom, których nauka, ustrój i urządzenie nie są przeciwne porządkowi publicznemu ani obyczajności publicznej ${ }^{9}$. Poza tym w Konstytucji marcowej można doszukać się uregulowania kwestii wyznaniowych także w innych artykułach, na przykład w art. 54, zawierającym tekst przysięgi prezydenckiej, czy w art. 120, który dotyczył nauki religii w szkołach ${ }^{10}$.

${ }^{6}$ Uznanie danego związku wyznaniowego za prawnie przyjęty następowało z reguły w drodze ustawodawczej, wraz z nadaniem mu statutu wewnętrznego. Pociągało to za sobą doniosłe konsekwencje prawne. Przez akt uznania związek wyznaniowy uzyskiwał system uprawnień przysługujący tylko takim związkom, przekształcając się w zorganizowaną społeczność religijną, której wewnętrzna struktura i władze zostały zaakceptowane przez władze państwowe. Gwarantowało to pełną autonomię i niezależność od mniej korzystnych przepisów ogólnoadministracyjnych. W zakresie prawa cywilnego związek taki otrzymywał osobowość prawną, dzięki czemu mógł działać z pełnymi skutkami prawnymi w stosunkach publicznych. Podział ten prowadził również do rozbieżności w ocenie pozycji prawnej poszczególnych związków wyznaniowych. Wpływały na to nieprecyzyjne określenia charakteru prawnego związków religijnych prawnie nieuznanych oraz odmienne regulacje sytuacji prawnej związków religijnych w poszczególnych dzielnicach. W związku z tym Ministerstwo Wyznań Religijnych i Oświecenia Publicznego podjęło prace nad ujednoliceniem wykładni obowiązujących przepisów i stworzeniem katalogu związków wyznaniowych. Prace zakończyły się wydaniem w 1935 roku urzędowego wykazu Kościołów i związków religijnych w Polsce; Ł. Baszak, op. cit., s. 132; zob. szerzej K. Krasowski, Związi wyznaniowe w II Rzeczypospolitej. Studium historycznoprawne, Warszawa-Poznań 1988, s. 58-59, 287-317; oraz J. Osuchowski, Prawo wyznaniowe w Rzeczypospolitej Polskiej 1918-1939, Warszawa 1967, s. 260-276.

7 Dz.U. RP z 1921 r. Nr 44, poz. 267.

8 H. Misztal, Polskie prawo wyznaniowe, Lublin 1996, s. 117-118.

9 Artykuły wyznaniowe Konstytucji marcowej omawiają m.in. J. Osuchowski, op. cit., s. 91100; K. Krasowski, op. cit., s. 54-61; S. Piekarski, Wyznania religijne w Polsce, Warszawa 1927, s. $1-15$.

10 P.A. Leszczyński, op. cit., s. 68.

Prawo 328, 2019

(C) for this edition by CNS 
Konstytucja kwietniowa z 1935 roku uchyliła ustawę z dnia 17 marca 1921 roku z wyjątkiem art. 99, 109-118 oraz $120^{11}$. W ten sposób artykuły wyznaniowe znajdujące się w rozdziale V Konstytucji marcowej obowiązywały także po wejściu w życie Konstytucji kwietniowej.

\section{Muzułmanie na ziemiach polskich}

Na ziemiach polskich po odzyskaniu niepodległości znaleźli się także muzułmanie, którymi byli przede wszystkim Tatarzy — potomkowie Tatarów osiedlających się od czasów Witolda i Jagiełły głównie na terenach Wielkiego Księstwa Litewskiego. Społeczność tatarska znalazła się na ziemiach Wielkiego Księstwa Litewskiego, a potem w Rzeczypospolitej Obojga Narodów w wyniku kolonizacji, której podłoże stanowiły czynniki o charakterze politycznym (odziały wojskowe), społecznym i gospodarczym. Jednak osadnictwo tatarskie głównie miało charakter wojskowy. W nagrodę za służbę wojskową Tatarzy uzyskiwali nadania ziemi ${ }^{12}$. Służba wojskowa należała do najstarszych zajęć, którymi parali się Tatarzy. Do czasu upadku Rzeczypospolitej istniały w wojsku polskim samodzielne pułki tatarskie, a w czasie wojen napoleońskich ponownie utworzono polską formację w sile jednego szwadronu. $Z$ upływem czasu Tatarzy zajmowali się głównie rolnictwem. W miastach tradycyjnym zawodem Tatarów polskich było garbarstwo. W drugiej połowie XIX wieku ukształtowała się wśród Tatarów grupa pracowników umysłowych, kiedy wielu z nich pracowało w służbie administracji rosyjskiej. W okresie II Rzeczypospolitej pracowali oni w urzędach magistrac-

11 Zob. art. 81 ust. 2. ustawy konstytucyjnej z dnia 23 kwietnia 1935 roku (Dz.U. z 1935 r. Nr 30, poz. 277).

12 Szerzej na temat osadnictwa Tatarów i jego położenia prawnego na ziemiach Wielkiego Księstwa Litewskiego zob. m.in. S. Kryczyński, Tatarzy litewscy. Próba monografii historyczno-etnograficznej, „Rocznik Tatarski” 3, 1938; J. Sobczak, Położenie prawne ludności tatarskiej w wielkim Księstwie Litewskim, Warszawa 1984; idem, Tatarzy w stużbie Rzeczypospolitej w drugiej połowie XVII i w XVIII w. Studium historycznoprawne, „Czasopismo Prawno-Historyczne” 1987, z. 1, s. 41-70; idem, Czy tatarska ludność Litwy należała do stanu szlacheckiego?, „Przegląd Historyczny" 1986, z. 3, s. 467-480; P. Borawski, Tatarzy dawnej Rzeczypospolitej, Warszawa 1986; idem, Położenie prawne Tatarów Wielkiego Księstwa Litewskiego, „Lituano-Slavica Posnaniensia” 2, 1987, s. 187-212; idem, O przynależności Tatarów hospodarskich do stanu szlacheckiego, s. 345358; P. Borawski, W. Sienkiewicz, Kilka uwag o książe Jacka Sobczaka pt. Położenie prawne ludności tatarskiej w Wielkim Księstwie Litewskim, KH 1986, z. 1, s. 149-164; P. Borawski, Tatarzy-ziemianie w dobrach Radziwiłtów (XVI-XVIII w.), „Przegląd Historyczny” 82, 1991, nr 1, s. 33-49; K. Grygajtis, Rozwój osadnictwa tatarskiego w Wielkim Księstwie Litewskim do końca XV wieku, „Piotrkowskie Zeszyty Historyczne” 5, 2003, s. 95-151.

Prawo 328, 2019

(C) for this edition by CNS 
kich, biurach sądowych i notarialnych, zakładach ubezpieczeń zdrowotnych, policji, na kolei i poczcie ${ }^{13}$.

Ludność muzułmańska w okresie II Rzeczypospolitej oscylowała w granicach od 5 do 6 tysięcy. Według danych sporządzonych przez GUS w 1927 roku w Rzeczypospolitej mieszkało ogółem 4971 muzułmanów, a w 1929 roku ponad 4770 (w województwie wileńskim 2300, w białostockim 664, nowogrodzkim 1776, poleskim 30, łódzkim 1) ${ }^{14}$. Poza tym na Polesiu w 1921 roku było 61 muzułmanów (najwięcej w powiecie łuninieckim i równieńskim).

W drugiej połowie XIX wieku Tatarzy z Powołża założyli również kolonię tatarską w Warszawie. W 1921 roku w stolicy zamieszkiwało 83 muzułmanów, a w 1938 roku warszawska gmina muzułmańska liczyła 197 członków. Należeli do niej oprócz Tatarów muzułmańscy emigranci z Rosji i przybysze z Bliskiego Wschodu ${ }^{15}$.

\section{Prace związane $\mathrm{z}$ uregulowaniem statusu prawnego wyznania muzułmańskiego W II RP}

W momencie odzyskania przez Polskę niepodległości sytuacja prawna muzułmanów opierała się na dawnych przepisach zaborczych. Należy przypuszczać, że na ziemiach byłego zaboru pruskiego muzułmanie podlegali ogólnie obowiązującym przepisom wyznaniowym, będąc związkiem wyznaniowym tolerowanym ${ }^{16}$. $\mathrm{Na}$ ziemiach byłego zaboru austriackiego wyznanie mahometańskie w obrządku hanefickim miało prawne uznanie na mocy ustawy z dnia 15 lipca 1912 roku

13 A. Miśkiewicz, Mniejszość tatarska w Polsce w latach 1918-1939, „Przegląd Historyczny" 77, 1986, nr 2, s. 243-245, 256-257.

14 J. Sobczak, Położenie prawne tatarskich wyznawców islamu w II Rzeczypospolitej, „Przegląd Historyczny" 79, 1988, nr 3, s. 501.

15 A. Miśkiewicz, op. cit., s. 242.

16 W systemie pruskim związki religijne traktowano niejednakowo. Można wyróżnić cztery grupy związków wyznaniowych: 1. związki wyznaniowe wyraźnie (publicznie) przez państwo uznane, o charakterze korporacji publicznoprawnych (kościoły ewangelickie i Kościół katolicki); 2. związki wyznaniowe przez państwo uznane, lecz nie uprzywilejowane, wyposażone także w uprawnienia osoby prawa publicznego, jednak nie korzystały z wszystkich uprawnień przyznanych kościołom uprzywilejowanym (bracia morawscy, staroluteranie); 3. związki wyznaniowe działające jako korporacje prywatnoprawne (baptyści, menonici); 4. związki wyznaniowe tolerowane, niemające praw korporacyjnych, które opierały swoją działalność na tolerancyjnych przepisach pruskiego prawa krajowego oraz konstytucji, wszystkim obywatelom przyznających prawo tworzenia stowarzyszeń religijnych, które były przez państwo tolerowane, o ile „wpajały swoim członkom uszanowanie względem Boga, wierność rządowi i moralne dobre zasady względem obywateli; zob. K. Krasowski, op. cit., s. 28-35.

Prawo 328, 2019

(C) for this edition by CNS 
w sprawie uznania wyznawców islamu obrządku hanefickiego za stowarzyszenie religijne. Natomiast na obszarze byłego zaboru rosyjskiego obowiązywały przepisy rosyjskie, czyli art. 1342-1415 tomu XI cz. I Zwodu praw Cesarstwa Rosyjskiego z 1832 roku - Swod zakonow Rossijskoj impierii (dalej: Zb. Pr. Ros. T. XI cz. 1) ${ }^{17}$ oraz ustawa z dnia 17 kwietnia 1905 roku o umocnieniu zasad tolerancji religijnej. Następnie postanowienie Tymczasowego Rządu Rosyjskiego z 20 marca 1917 roku o uchyleniu wyznaniowych i narodowościowych ograniczeń, które wprowadzało zasadę równości obywateli i uchylało wszystkie rozporządzenia władz wykonawczych wydanych w kwestiach religijnych i narodowościowych, które były sprzeczne z zasadą wolności sumienia. Jednak postanowienie to dotyczyło tylko części Kresów Wschodnich pozostających pod władaniem armii rosyjskiej, a więc części Wileńszczyzny, Mińszczyzny i Wołynia, nie obejmując swym zakresem pozostałych Kresów Wschodnich i ziem kongresowych, ze względu na okupację niemiecką. Zniesienie ograniczeń na tych ziemiach nastąpiło na mocy rozporządzenia komisarza generalnego ziem wschodnich z 15 maja 1919 roku (Dziennik Rozporządzeń komisarza generalnego ziem wschodnich z 1919 roku, $\mathrm{nr} 23)^{18}$.

Kolejnym krokiem zmierzającym do zniesienia ograniczeń wyznaniowych wynikających z przepisów rosyjskich było wydanie dekretu przez Tymczasową Komisję Rządzącą Litwy Środkowej z 17 listopada 1920 roku, który kasował wszelkie ograniczenia ustawodawstwa rosyjskiego wypływające z przynależności obywateli do wyznania i narodowości. Warto jeszcze dodać, że najwyższa instancja sądowa byłej Litwy Środkowej (Izba Kasacyjna) wydała orzeczenie z dnia 13 marca 1922 roku, będące pierwszym aktem sądowym, który zniósł wszystkie ograniczenia wyznaniowe na podstawie ogólnego ducha obowiązujących ustaw, mimo że odnośne przepisy nie zostały jeszcze uchylone ${ }^{19}$.

Sytuacja się zmieniła w momencie przyłączenia tak zwanej Litwy Środkowej do obszaru Rzeczypospolitej i rozciągnięcia na ten teren przepisów Konstytucji marcowej ${ }^{20}$. Wydawać by się mogło, że w związku z tym przepisy prawa rosyjskiego dyskryminujące ludność muzułmańską przestaną obowiązywać. Takie opinie wydał Sąd Najwyższy (orzeczenie z dnia 16 listopada 1924 roku), który uznał, że prawa sprzeczne z zasadami konstytucji tracą swoją moc. Jednak inne stanowisko zajął Najwyższy Trybunał Administracyjny (orzeczenie z dnia 10 października 1924 roku), który uznał, że przepisy niezgodne z Konstytucją nie zostały uchylone przez samo jej wejście w życie i ich uchylenie powinno nastąpić w drodze normalnej procedury ustawodawczej. W ślad za orzeczeniem Najwyższego Trybunału Administracyjnego wydano reskrypt ministerstwa wyznań religijnych

17 J. Sawicki, Studia nad położeniem prawnym mniejszości religijnych w państwie polskim, Warszawa 1937, s. 180.

18 Szerzej A. Achmatowicz, Zarys stanu prawnego wyznania muzulmańskiego w b. Rosji i wspótczesnej Polsce, „Rocznik Tatarski” 1, 1932, s. 102-103.

19 Szerzej o tym ibidem, s. 103-105.

20 Ustawa konstytucyjna z dnia 17 marca 1921 roku (Dz.U. RP z 1921 r. Nr 44, poz. 267).

Prawo 328, 2019

(C) for this edition by CNS 
i oświecenia publicznego z dnia 13 listopada 1924 roku $^{21}$. Reskrypt ten został rozesłany za pośrednictwem lokalnych władz do wszystkich duchownych wyznania muzułmańskiego, izraelickiego i karaimskiego. Duchowieństwo muzułmańskie nie zareagowało stanowczo na te postanowienia, co wywołało wyraźny sprzeciw Aleksandra Achmatowicza ${ }^{22}$, który uważał, że w tym przypadku nie miały zastosowania nauki islamu zakazujące muzułmanom znajdującym się na terytorium państwa chrześcijańskiego stawiania oporu wobec ustaw tego państwa, ponieważ reskrypt ten był sprzeczny z postanowieniami Konstytucji marcowej. W związku z tym Achmatowicz złożył do laski marszałkowskiej Senatu (1929 rok) wniosek o wezwanie rządu do przedstawienia Sejmowi projektu ustawy uchylającej wszelkie ograniczenia wyznaniowe i narodowościowe. Podobne wnioski składane były także przez innych parlamentarzystów ${ }^{23}$.

W wyniku tych działań Sejm wydał ustawę z dnia 20 marca 1931 roku o wygaśnięciu mocy prawnej przepisów wyjąatkowych, związanych z pochodzeniem, narodowością, językiem, rasą lub religią obywateli Rzeczypospolitej Polskiej ${ }^{24}$. Na mocy postanowień tej ustawy przestały obowiązywać wszelkie przepisy ograniczające kwestie wyznaniowe, narodowościowe, rasowe i językowe, w tym reskrypt z dnia 13 listopada 1924 roku $^{25}$. Tym samym odnośnie do wyznania muzułmańskiego utraciły moc obowiązującą art. 1342-1415 Zb. Pr. Ros. T. XI cz. 1, czyli wszystkie przepisy dotyczące ustroju władz duchownych muzułmańskich ${ }^{26}$.

Poza problemami związanymi z uchyleniem przepisów rosyjskich należało zająć się kwestią uregulowania statusu prawnego wyznania muzułmańskiego. Muzułmanie zamieszkujący w Polsce formalnie byli podporządkowani muftiemu stojącemu na czele Taurydzkiego Muzułmańskiego Zarządu Duchowego w Symferopolu, który został zlikwidowany w wyniku rewolucji październikowej. Wśród nich wyłoniły się dwa ośrodki pretendujące do odegrania wiodącej roli w świecie polskich muzułmanów. Mowa tu o Warszawie, gdzie utworzono Związek Muzułmański miasta stołecznego Warszawy, którego statut został zatwierdzony przez

21 Pełna treść reskryptu, zob. A. Achmatowicz, op. cit., s. 107.

22 Aleksander Achmatowicz (1865-1944) — prawnik, w styczniu 1918 roku delegat na Wszechrosyjski Zjazd Muzułmanów, minister sprawiedliwości w krótkotrwałym rządzie krymskim gen. Sulejmana-Sulkiewicza. W niepodległej Polsce jeden z inicjatorów utworzenia w 1919 roku pułku jazdy tatarskiej im. płk. Mustafy Achmatowicza. Senator II kadencji (1928-1939), członek Klubu senackiego Bezpartyjnego Bloku Współpracy z Rządem (BBWR), cyt. za: S. Dzięciołowski, Aneks - Z dziejów parlamentaryzmu polskiego. Ustawy o muzulmańskim i karaimskim zwiąkach wyznaniowych, „Kronika Sejmowa” 2001, nr 14 (495), s. 9, http://archive.today/OT15A (dostęp: 16 czerwca 2019).

23 A. Achmatowicz, op. cit., s. 105-108.

24 Dz.U. RP z 1931 r. Nr 31, poz. 214.

25 Szczegółowy wykaz przepisów, które przestały obowiązywać na podstawie ustawy z dnia 13 marca 1931 roku zamieścił A. Achmatowicz; zob. idem, op. cit., s. 108-110.

${ }^{26}$ Ibidem, s. 112. Inaczej J. Sawicki, który uważał uznanie wszystkich bez wyjątku przepisów rosyjskich dotyczących muzułmanów za zniesione w państwie Polskim za daleko idące; zob. J. Sawicki, op. cit., s. 180. 
Ministerstwo Spraw Wewnętrznych 14 grudnia 1923 roku. Natomiast w Wilnie działał Centralny Komitet Tatarów Polski, Litwy, Białorusi i Ukrainy, który został przeniesiony w kwietniu 1919 roku z Piotrogrodu, oraz reaktywowana w 1922 roku Muzułmańska Gmina Wyznaniowa kierowana przez Zarząd Duchowy, działająca niezależnie od Centralnego Komitetu Tatarów. Obydwa ośrodki starały się powołać w swoich miastach naczelne władze muzułmańskie w Polsce ${ }^{27}$. Pierwsze próby uregulowania położenia prawnego wyznania muzułmańskiego podjęto w maju 1923 roku z inicjatywy Centralnego Komitetu Związku Tatarów zamieszkałych w Polsce i gminy muzułmańskiej w Wilnie. W piśmie skierowanym do prezydenta Rzeczypospolitej Polskiej Stanisława Wojciechowskiego prezes komitetu Aleksander Achmatowicz i zwierzchnik gminy wileńskiej Adam Murza-Murzicz wystąpili z prośbą o zniesienie zależności gmin muzułmańskich od muftiatu krymskiego i utworzenie muftiatu w Wilnie oraz o wydanie ustawy regulującej stosunek państwa do gmin muzułmańskich ${ }^{28}$. W memoriale tym postulowano także, aby polscy wyznawcy podlegali zwierzchnictwu religijnemu kalifa konstantynopolskiego. Poza tym proszono, aby w Wilnie utworzono państwową szkołę muzułmańską, która miałaby współpracować z Uniwersytetem w Konstantynopolu. Ważną kwestią poruszoną w tym piśmie była również prośba o przyznanie duchownym muzułmańskim stałego wynagrodzenia i dotacji na utrzymanie meczetów. W wyniku wystosowania tego pisma władze centralne zainteresowały się sytuacją polskich muzułmanów i zleciły delegatowi rządu w Wilnie oraz wojewodom północno-wschodnich województw nadesłanie sprawozdania o zamieszkujących te tereny wyznawcach islamu.

Zainicjowanie zabiegów mających na celu uregulowanie sytuacji prawnej gmin muzułmańskich doprowadziło do nawiązania współpracy między ośrodkiem wileńskim i Warszawskim Związkiem Muzułmańskim, które począwszy od 1924 roku, rozpoczęły wspólne narady i konferencje. Wprawdzie nie udało się ustalić lokalizacji siedziby przyszłych naczelnych władz muzułmańskich, jednak prace nad najważniejszą kwestią, czyli nad projektem aktu prawnego regulującego zasady organizacyjne oraz sytuację prawną polskich muzułmanów, przebiegały pomyślnie ${ }^{29}$.

Efektem wspólnych działań były Tymczasowe przepisy o organizacji Kościoła Mahomateńskiego w Polsce (dalej: Tymczasowe przepisy), które zostały przekazane Ministerstwu Wyznań Religijnych i Oświecenia Publicznego pismem z dnia 10 stycznia 1925 roku przez Związek Muzułmański miasta stołecznego Warszawy. Tymczasowe przepisy składały się z 42 paragrafów zebranych w pięciu rozdziałach. W kwestii organizacji związku religijnego widoczna była zależność od przepisów ukształtowanych w Zwodzie praw. W przepisach tych zna-

27 Szerzej o tym J. Sobczak, Położenie prawne tatarskich..., s. 502-503.

28 K. Krasowski, op. cit., s. 197; J. Sobczak, Położenie prawne tatarskich..., s. 503.

29 J. Sobczak, Położenie prawne tatarskich..., s. 503-504. 
lazły się postanowienia dotyczące zwierzchnika polskich muzułmanów, którym miał być mufti, wybierany dożywotnio przez Kongres Mahometański. Poza tym znalazły się tam przepisy dotyczące imamów i muezzinów, którzy mieli dokonywać czynności religijnych, a imam ponadto miał prowadzić akta stanu cywilnego. W osobnym rozdziale znalazły się postanowienia związane ze sprawami majątkowymi. Na oryginale tekstu wprowadzono wiele odręcznych poprawek i zmian, które wprowadził najprawdopodobniej Stanisław Piekarski, ówczesny dyrektor Departamentu Wyznań Religijnych. Dotyczyły one chociażby kwestii skreślenia wszystkich przepisów rozdziału IV dotyczącego spraw majątkowych, a także skreślenia przepisu o prowadzeniu ksiąg stanu cywilnego przez imamów, dożywotności urzędu muftiego i osobowości prawnej związku ${ }^{30}$.

Projekt Tymczasowych przepisów wraz z pismem Ministerstwa Spraw Zagranicznych z dnia 21 stycznia 1925 roku wskazujące na pilną potrzebę uregulowania sytuacji prawnej wyznawców islamu ze względu na politykę zagraniczną był przedmiotem konferencji międzyministerialnej zwołanej 28 stycznia 1925 roku. Jej przebieg wskazał na poważne rozbieżności między Ministerstwem Wyznań Religijnych i Oświecenia Publicznego a Ministerstwem Sprawiedliwości. Radca Ministerstwa Sprawiedliwości M. Borowski proponował wydać Tymczasowe przepisy w drodze rozporządzenia ministra, opublikowanego w Dzienniku Ustaw. Nie zgodził się z tym delegat Ministerstwa Sprawiedliwości P. Cheliński, który opowiadał się za przyjęciem trybu regulacji określonym w art. 115 Konstytucji, stwierdzając w konkluzji, że minister wyznań mógłby tymczasowym aktem administracyjnym zaakceptować statut wewnętrzny, co przyniosłoby dobry efekt polityczny. Dyrektor Departamentu Wyznań S. Piekarski zaproponował powołać rozporządzeniem ministra wyznań prawną reprezentację wyznania muzułmańskiego, która zajęłaby się rokowaniami o przyszłą ustawę. Koncepcja ta opierała się na precedensie, jakim było tymczasowe uregulowanie sytuacji prawnej Kościoła prawosławnego rozporządzeniem z dnia 30 stycznia 1922 roku $^{31}$.

Projekt tego rozporządzenia sformułowano na konferencji międzyministerialnej i oparto na postanowieniach Tymczasowych przepisów. Przedstawiono go Komitetowi Politycznemu Rady Ministrów, który skrytykował rozwiązania podjęte na konferencji. Uznano, że w świetle art. 3 i 44 Konstytucji rozwiązania przyjęte przez komisję międzyministerialną nie mają żadnych podstaw prawnych. Jednak widząc konieczność i wagę całego zagadnienia związanego z uregulowaniem położenia prawnego wyznania muzułmańskiego, zalecono Ministrowi Wyznań Religijnych i Oświecenia Publicznego wydanie wewnętrznego zarządzenia, nigdzie nie ogłaszanego, wyrażającego zgodę na przeprowadzenie wyborów muftiego

30 Więcej o Tymczasowych przepisach, J. Sobczak, Polożenie prawne tatarskich..., s. 504-507.

31 K. Krasowski, op. cit., s. 197-198; szerzej o pracach w komisji międzyministerialnej J. Sobczak, Położenie prawne tatarskich..., s. 507-508. 
i zastrzegające ostateczne uregulowanie położenia związku muzułmanów według postanowień art. 115 Konstytucji marcowej ${ }^{32}$.

Zgodnie z tymi ustaleniami rozpoczęto działania zmierzające do zorganizowania zjazdu przedstawicieli wyznania muzułmańskiego ${ }^{33}$, w celu wyłonienia prawnej reprezentacji związku, której udział w pracach legislacyjnych nad ustawą regulującą sytuację prawną tego wyznania przewidywał art. 115 Konstytucji marcowej.

Ostatecznie Wszechpolski Zjazd Delegatów Gmin Muzułmańskich rozpoczął swoje obrady 28 grudnia 1925 roku. W wyniku dwudniowego głosowania wybrano na urząd muftiego Jakuba Szynkiewicza ${ }^{34}$, a na jego zastępcę płk. Jakuba Romanowicza. Poza wyborem muftiego powołano także Komisję Prawniczą $^{35}$, której powierzono opracowanie projektu statutu wewnętrznego. Komisja przesłała do ministerstwa Wyznań Religijnych i Oświecenia Publicznego ostateczny projekt ustawy i statutu dopiero 18 stycznia 1932 roku. Jednak propozycje komisji nie zostały uwzględnione przy dalszych pracach legislacyjnych. Wiązało się to z konfliktem ${ }^{36}$ pomiędzy nowo wybranym muftim J. Szynkiewiczem a Komisją Prawniczą i Związkiem Kulturalno-Oświatowym Tatarów ${ }^{37}$. Przyjmuje się, że początek istnienia Muzułmańskiego Związku Religijnego w Rzeczypospolitej Polskiej miał miejsce właśnie podczas obrad Wszechpolskiego Zjazdu Delegatów Gmin Muzułmańskich ${ }^{38}$. Warto w tym miejscu dodać, że Muzułmański Związek Religijny zaliczano w tym okresie do związków religijnych prawnie uznanych z nieuregulowanym stosunkiem do państwa ${ }^{39}$.

Ministerstwo Wyznań Religijnych i Oświecenia Publicznego rozpoczęło prace legislacyjne po przesłaniu przez muftiego J. Szynkiewicza projektu ustawy

32 K. Krasowski, op. cit., s. 198-199; J. Sobczak, Położenie prawne tatarskich..., s. 509.

33 Szerzej o tym J. Sobczak, Położenie prawne tatarskich..., s. 509-511.

34 Jakób Szynkiewicz (1884-1966) — studiował języki wschodnie w Petersburgu i Berlinie, gdzie w 1925 roku uzyskał tytuł doktora filozofii. W grudniu 1925 roku Wszechpolski Zjazd Muzułmanów wybrał go zaocznie muftim muzułmanów RP. Objął to stanowisko i następnie uczestniczył w Światowym Kongresie Muzułmanów w Kairze w 1926 roku, cyt. za: S. Dzięciołowski, op. cit., s. 9.

35 W skład Komisji Prawniczej weszli Aleksander Achmatowicz, Adam Murza-Murzicz, Bohdan Achmatowicz, Aleksander Połtórzycki i Mohamed Waisow; zob. J. Sobczak, Położenie prawne tatarskich..., s. 511.

36 Szerzej na temat konfliktu pomiędzy J. Szynkiewiczem, a Komisją Prawniczą i Związkiem Kulturalno-Oświatowym Tatarów oraz projekcie patrz J. Sobczak, Położenie prawne tatarskich..., s. $512-516$.

37 Związek Kulturalno-Oświatowy powołany został w 1925 roku. Głównym zadaniem związku miała być szeroko zakrojona działalność o charakterze kulturalno-oświatowym we wszystkich skupiskach tatarskich; zob. A. Miśkiewicz, op cit., s. 252-256.

38 Ibidem, s. 246; P. Borecki, Obsada godności Muftiego Muzulmańskiego Związu Religijnego a zasady Konstytucji RP, „Studia Prawnicze” 2018, nr 1, s. 8. Muzułmański Związek Religijny w Rzeczypospolitej Polskiej, Historia MZR w RP, http://mzr.pl/historia-mzr-w-rp/ (dostęp: 16 czerwca 2019).

39 Zob. S. Grelewski, Wyznania protestanckie i sekty religijne w Polsce wspótczesnej. Zarys stanu prawnego wyznań religijnych w Polsce, Sandomierz 1935, s. 26; J. Sawicki, op. cit., s. 180.

Prawo 328, 2019

(C) for this edition by CNS 
o stosunku państwa do Kościoła muzułmańskiego, który został opracowany bez udziału członków Komisji Prawniczej. Ministerstwo potraktowało ten projekt jako płaszczyznę do dalszych negocjacji, uznając J. Szynkiewicza za jedynego prawnego przedstawiciela wyznania muzułmańskiego. Projekt ustawy oraz statutu poddano siedmiu kolejnym redakcjom, a następnie po uzgodnieniu z muftim i Departamentem Oświaty w resorcie wyznań przesłano do zainteresowanych ministerstw. Uwagi do projektu zgłosiło Ministerstwo Skarbu i Ministerstwo Rolnictwa i Reform Rolnych, w związku z czym 1 czerwca 1934 roku zwołano konferencję międzyministerialną, w trakcie której porozumiano się co do całości projektu z wyjątkiem art. 45 ustawy, dotyczącym zwolnienia od opodatkowania nieruchomości związku, tak zwanej ziemi wakufowej ${ }^{40}$. Sprzeciwiał się temu Minister Skarbu, który argumentował swój sprzeciw tym, że żaden związek religijny w Polsce nie korzystał z takiego przywileju. Ostatecznie przyjęto rozwiązanie proponowane przez Ministra Skarbu. Dalsze poprawki zostały wprowadzone przez Biuro Prawne Prezydium Rady Ministrów ${ }^{41}$.

Oficjalne porozumienie między Muzułmańskim Związkiem Religijnym a władzami państwowymi nastąpiło 3 grudnia 1934 roku w Urzędzie Wojewódzkim w Wilnie w obecności wojewody wileńskiego Władysława Jaszczołta oraz muftiego J. Szynkiewicza, jego zastępcy płk. Jakuba Romanowicza i sekretarza muftiatu Stefana Tuhan-Baranowskiego. Mufti wręczył Franciszkowi Potockiemu, dyrektorowi Departamentu Wyznań, podpisany przez siebie ostateczny tekst projektu statutu. Następnie odczytano projekt rozporządzenia Prezydenta Rzeczypospolitej z mocą ustawy o stosunku państwa do Muzułmańskiego Związku Religijnego, który został podpisany przez muftiego. $Z$ nieznanych przyczyn po kilku dniach zrezygnowano $\mathrm{z}$ formy rozporządzenia z mocą ustawy ${ }^{42}$.

Ostatecznie projekt ustawy o stosunku państwa do Muzułmańskiego Związku Religijnego, po zaakceptowaniu go przez Biuro Prawne Prezydium Rady Ministrów, został przyjęty przez Radę Ministrów na posiedzeniu w dniu 7 grudnia 1935 roku. Liczył on 49 artykułów, w tym dołączone do niego uzasadnienie, w którym pokrótce przedstawiono motywy przygotowania tego projektu ${ }^{43}$.

40 Ziemia wakufowa, czyli grunty przeznaczone na utrzymanie imama i meczetu, których było nie więcej niż 240 ha; zob. J. Sobczak, Położenie prawne tatarskich..., s. 517.

41 K. Krasowski, op. cit., s. 199-200.

42 J. Sobczak, Położenie prawne tatarskich..., s. 518.

43 Rządowy projekt ustawy o stosunku Państwa do Muzułmańskiego Związku Religijnego w Rzeczypospolitej Polskiej, druk Sejmu nr 24 z 1936 roku. Uzasadnienie dołączone do projektu: „Z chwilą powstania niepodległości Polski wyznanie muzułmańskie w Polsce zostało pozbawione władzy zwierzchniej, bowiem głową tego wyznania w dawnej Rosji był Mufti muzułmański, rezydujący w Symferopolu na Krymie, którego zwierzchnictwo duchownemu podlegali wszyscy Muzułmanie, znajdujący się w granicach Państwa rosyjskiego na obszarach, położonych na zachód od Dniepru. Pozatem wyznanie to opierało swój byt prawny na przepisach rosyjskich, przestarzałych i nieodpowiadających nowym warunkom, w których się to wyznanie znalazło. Ten stan rzeczy wymagał zorganizowania polskich Muzułmanów w oddzielny związek religijny, niezależny od ja- 
Następnie projekt rządowy został skierowany do Sejmu. Wtedy swoje krytyczne stanowisko co do sposobu rokowań oraz kształtu samego projektu przedstawili członkowie Komisji Prawniczej. W piśmie z dnia 22 lutego 1936 roku, skierowanym do Marszałka Senatu, kwestionowali oni zasadność porozumiewania się z rządem muftiego. Uważali oni, że upoważniona do tego była Komisja Prawnicza, która miała negatywny stosunek do kształtu projektu przesłanego przez muftiego, ponieważ niektóre z postanowień były zaczerpnięte z przepisów rosyjskiej ustawy wyznań obcych, co zdaniem członków Komisji Prawniczej było niezgodne z Konstytucją, a także z zasadami wyznania muzułmańskiego. Protest Komisji Prawniczej został uznany przez Ministerstwo Wyznań Religijnych i Oświecenia Publicznego za bezpodstawny, ponieważ według ministerstwa jedynym prawnym reprezentantem ludności muzułmańskiej jest mufti. W związku $\mathrm{z}$ tym uzgodnienie $\mathrm{z}$ muftim projektu ustawy wyczerpywało dyspozycję art. 115 Konstytucji marcowej ${ }^{44}$.

kichkolwiek władz obcokrajowych duchownych, czy świeckich i nowego uregulowania jego położenia prawnego w oparciu o ustawę polską. Pierwszym krokiem na tej drodze był wybór Muftiego muzułmańskiego w Polsce, dokonany przez wszechpolski zjazd delegatów ludności muzułmańskiej w Wilnie, w dniach od 28-29 grudnia 1925 r., przyjęty do wiadomości przez Ministra Wyznań Religijnych i Oświecenia Publicznego pismem z dnia 1 marca 1926 r. L. 1760/26. Na tym zjeździe wyłoniono jednocześnie komisję prawniczą dla przygotowania projektu nowej organizacji Wyznania Muzułmańskiego. Następnym z kolei krokiem na tej drodze musiało być opracowanie projektu ustawy o stosunku Państwa do tego wyznania. Przedłożony tu projekt czyni zadość temu postulatowi. Reguluje on stosunek Państwa do Wyznania Muzułmańskiego i daje podstawy, na których będzie się mógł oprzeć dalszy jego byt i rozwój na ziemiach Rzeczypospolitej. Formy zorganizowania całości prawnej Wyznania Muzułmańskiego i uregulowania jego położenia prawnego idą po linji stworzenia nowego ładu prawnego, przystosowanego do wymogów współczesnego życia, obowiązujące bowiem do dnia dzisiejszego przepisy dawnego państwa rosyjskiego — zawarte w §§ 342-1415 tomu XI cz. I Zbioru praw b. ces. ros. — są zupełnie niezdatne do użytku w dzisiejszych warunkach. Zresztą obcość tych praw i ich niezgodność z duchem państwowości polskiej wymagała ich zmienienia, nie mówiąc już o tem, że przepisy rosyjskie były z istoty swej treści przestarzałe i nieprzystosowane do nowoczesnego organizmu państwowego. Nowy projekt ustawy o stosunku Państwa do Muzułmańskiego Związku Religijnego w Rzeczypospolitej uwzględnia w najszerszym możliwie zakresie tak potrzeby wyznania muzułmańskiego, jak i postulaty prawodawstwa polskiego w dziedzinie wyznaniowej. Jednocześnie rozciąga on na cały obszar Rzeczypospolitej przepisy prawne, odnoszące się do wyznania muzułmańskiego, pozwalające mu korzystać z dobrodziejstw ustawy na całym terenie Państwa, a nie, jak dotąd było, w niektórych tylko jego częściach. Przyczynia się tym sposobem do unifikacji ustawodawstwa wyznaniowego w Polsce. Załączony projekt ustawy o stosunku Państwa do Muzułmańskiego Związku Religijnego R. P., uwzględniając wszystkie wymogi współczesności polskiej oraz potrzeby wyznaniowe Muzułmanów, opracowany został po porozumieniu się z prawnym reprezentantem Wyznania Muzułmańskiego w Polsce, Muftim dr. Jakóbem Szynkiewiczem, zgodnie z brzmieniem art. 115 ust. drugi, Konstytucji z dn. 17.III.1921 r., który to artykuł zachowuje moc prawną na podstawie art. 81 ustawy konstytucyjnej z dn. 23.IV.1935 r.”.

44 K. Krasowski, op. cit., s. 200; J. Sobczak, Położenie prawne tatarskich..., s. 518.

Prawo 328, 2019

(C) for this edition by CNS 


\section{Prace legislacyjne w Sejmie i Senacie}

Efektem końcowym prac podjętych przez władze państwowe i muftiego był rządowy projekt ustawy o stosunku Państwa do Muzułmańskiego Związku Religijnego w Rzeczypospolitej Polskiej uchwalony przez Radę Ministrów 7 grudnia 1935 roku i wniesiony do laski marszałkowskiej pismem Ministra Wyznań Religijnych i Oświecenia Publicznego z dnia 10 grudnia 1935 roku Nr I. Praw. 1012/70/35

Projekt trafił do Komisji Oświatowej, która po rozpatrzeniu go na posiedzeniu w dniu 4 lutego 1936 roku wystąpiła z wnioskiem do Sejmu, aby ten projekt uchwalić bez poprawek ${ }^{46}$. W dniu 7 lutego 1936 roku na dziewiątym posiedzeniu Sejmu IV kadencji sprawozdanie Komisji Oświatowej o rządowym projekcie ustawy o stosunku Państwa do Muzułmańskiego Związku Religijnego złożył poseł Borys Pimonow ${ }^{47}$, który w swoim przemówieniu nawiązał do polityki narodowościowej RP opartej na zasadzie tolerancji oraz do roli Tatarów polskich w historii Rzeczypospolitej, głównie ich udziału w walkach po stronie Polski. Na koniec przedstawił ogólną charakterystykę ustawy ${ }^{48}$.

45 J. Sawicki, op. cit., s. 181.

46 Sprawozdanie Komisji Oświatowej o rządowym projekcie ustawy o stosunku Państwa do Muzułmańskiego Związku Religijnego w Rzeczypospolitej Polskiej, Druk Sejmu nr 57 z 1936 r.

47 Borys Pimonow (1901-1961) — Rosjanin, absolwent Uniwersytetu Wileńskiego i Politechniki Warszawskiej, inżynier architekt. Od 1931 roku prezes Związku Rosyjskich Organizacji Mniejszościowych w Polsce, zarazem wiceprzewodniczący Rady Naczelnej Staroobrzędowców w Polsce. Poseł na Sejm III i IV kadencji z okręgu wileńskiego, cyt. za: S. Dzięciołowski, op. cit., s. 9.

48 „Wysoki Sejmie! Rzeczpospolita Polska przedrozbiorowa potrafiła promieniować urokiem swoich swobód obywatelskich na ludy i państwa ościenne. Źródłem tego uroku było to, że dzieje Polski posiadają najpiękniejsze i najbardziej pełne przykłady tolerancji państwa pod względem wyznań religijnych. Tolerancję tę dałoby się ująć w formułę: pełna autonomia, wewnętrzne uszanowanie wierzeń religijnych i swoboda kultu. Dlatego też w okresach, gdy ta odwieczna zasada tolerancji nie była zniekształcana lub zaniedbywana dla jakichś chwilowych politycznych koncepcji, gdy wielki dzwon państwowości Rzeczypospolitej Polskiej w potrzebie wzywał do wspólnego wysiłku zbrojnego wszystkich swoich obywateli, lub gdy głosił o jej mocarstwowym powołaniu, głos tego dzwonu grzmiał pełnym i przekonywującym brzmieniem. Nie sposób przecież wydobyć z najpiękniejszego nawet instrumentu, jakim jest państwo, pełnych jego wartości, jeżeli uderzać tylko w jedne klawisze, a pomijać inne. Taki mistrz, któryby zechciał w ten sposób posługiwać się swoim instrumentem, dałby dowód, że nie zna pełnej wartości i możliwości swego instrumentu. Dlatego też z radością konstatuję, że ciągłe i pracowite dążenia kierowników naszej nawy państwowej do nawiązania w swojej polityce narodowościowej i wyznaniowej do dawnych tradycji Rzeczypospolitej znajdują swój nowy konkretny wyraz w opracowanych dzisiaj projektach ustaw. Omawiany projekt reguluje podstawy prawne istnienia w naszym państwie Muzułmańskiego Związku Religijnego Rzeczypospolitej Polskiej. Stwarzając te podstawy prawne, projekt ten uznaje jednocześnie organizację wewnętrzną tego związku, w myśl kanonów tego wyznania i jego tradycyjnej formy ustrojowej. Ustawa ta reguluje stosunek prawny do wyznania muzułmanów. W Polsce stosunkowo nieliczna grupa Tatarów, którzy należą do wielkiej rodziny świata muzułmańskiego i którzy od wieków, od wieku XIV — związali swój los z losem Rzeczypospolitej Polskiej. Od czasów, gdy carewicz Szek Elen-Dźim powołany przez Witolda, dopomógł do zwycięskiej bitwy pod Grunwaldem, trady-

Prawo 328, 2019

(C) for this edition by CNS 
Po złożeniu sprawozdania przez posła Pimonowa przystąpiono do głosowania. Nikt nie zgłosił pytań. Projekt ustawy o stosunku Państwa do Muzułmańskiego Związku Religijnego w Rzeczypospolitej Polskiej został przyjęty w całości przez Sejm w pierwszym, drugim i trzecim czytaniu ${ }^{49}$. Następnie projekt ustawy trafił do senackiej Komisji Prawniczej, która analizowała go na posiedzeniach w dniach 18 i 27 lutego 1936 roku$^{50}$. Sprawozdanie Komisji Prawniczej o projekcie ustawy o stosunku Państwa do Muzułmańskiego Związku Religijnego w Rzeczypospolitej Polskiej przedstawił na siódmym posiedzeniu Senatu w dniu 6 marca 1936 roku senator Zygmunt Beczkowicz ${ }^{51}$. W swoim wystąpieniu poruszył kwestię pojawienia się Tatarów na ziemiach polskich w XIV wieku. Opisana została ich rola w państwie polskim w ciągu wieków. Ponadto przedstawiono sy-

cją waleczności Tatarów, tradycja ciągłej współpracy i składania dowodów swego przywiązania do ziemi i Państwa, ten nieduży naród, reprezentujący dziś na ziemiach Rzeczypospolitej Polskiej zaledwie 7.000 wiernych i tworzący zaledwie 19 gmin wyznaniowych, potrafił jednak wytworzyć tradycję wzruszenia. Jest to tradycja pełna romantyzmu, pełna dowodów waleczności i szlachetności. W czasach najgorszych, które przeszła Rzeczpospolita, ten mały naród był jednak zawsze po stronie Rzeczypospolitej Polskiej, czy to było w czasach wojen najdawniejszych, czy to w czasach już porozbiorowych, czy w czasie wojen napoleońskich, czy nawet w czasie powstań $1831 \mathrm{r}$. czy w 1863 r., a nawet ostatnio w pracach niepodległościowych naród ten był zawsze z narodem polskim. Szereg nazwisk, pochodzących ze starych rodów tatarskich, a posiadających szlachectwo polskie chlubie zapisało się na kartach dziejów Rzeczypospolitej. Dość wspomnieć tu nazwiska Ahmatowicza i Sulkiewicza, aby się przekonać, że te nazwiska nie są nam obce. Ustawa, którą dziś rozpatrujemy, reguluje definitywnie stosunek prawny Państwa do tego wyznania. Uregulowanie tego stosunku, spowodowane zostało tym stanem, który się wytworzył z chwilą wskrzeszenia Państwa Polskiego. Bowiem ustawodawstwo, regulujące na ziemiach naszych za czasów Imperjum Rosyjskiego to zagadnienie, nie dałoby się ani w części zastosować w obecnych warunkach. Jednym z najbardziej charakterystycznych i niemiłych dla Tatarów momentów tego dawniejszego ustawodawstwa było to, że głowa tego kościoła nie miała miejsca pobytu w pobliżu swoich wyznawców, lecz przebywała stale w Symferopolu. Ustawa ta zapewnia temu wyznaniu zupełną swobodę wewnętrznego rządzenia się w granicach Rzeczypospolitej i pozwala mu na istnienie samodzielne i niezawisłe od jakichkolwiek związków religijnych muzułmańskich, znajdujących się poza obrębem Państwa, aczkolwiek nie przesądza łączności duchowej i religijnej z innymi muzułmanami na wschodzie. Ustawa ta jest wynikiem porozumienia prawnej reprezentacji muzułmanów z władzami naszymi, z Rządem i jest obustronnie zaakceptowana. Zapewnia ona z jednej strony całkowitą swobodę i wolność temu wyznaniu w Państwie Polskim i jednocześnie w dostatecznej mierze gwarantuje Państwu wszelkie prawa i możność ingerencji w razie potrzeby i dlatego nie nasuwa żadnych wątpliwości”; zob. Sprawozdanie stenograficzne Sejmu Rzeczypospolitej Polskiej IV Kadencji z 9 posiedzenia w dniu 7 lutego 1936 roku, s. 6-7.

49 Sprawozdanie stenograficzne Sejmu Rzeczypospolitej Polskiej IV Kadencji z 9 posiedzenia w dniu 7 lutego 1936 roku, s. 7.

50 Sprawozdanie Komisji Prawniczej o projekcie ustawy o stosunku Państwa do Muzułmańskiego Związku Religijnego w Rzeczypospolitej Polskiej, uchwalonym przez Sejm w dniu 7 lutego 1936 roku, druk Senatu nr 22 z 1936 r.

51 Zygmunt Beczkowicz (1887-1955) — prawnik, od 1926 roku wojewoda warszawski, od 1926 roku nowogródzki, od 1931 roku wojewoda wileński. W 1935 roku poseł i minister pełnomocny RP w Rydze. Senator IV kadencji powołany prze Prezydenta RP, członek senackiego Koła Obozu Zjednoczenia Narodowego, cyt. za: S. Dzięciołowski, op. cit., s. 9.

Prawo 328, 2019

(C) for this edition by CNS 
tuację prawną i organizacyjną Tatarów po odzyskaniu przez Polskę niepodległości ${ }^{52}$. Senacka Komisja Prawnicza nie miała uwag co do treści ustawy. Zgłoszono

52 „Wysoka Izbo! Ustawa o stosunku Państwa do Muzułmańskiego Związku Religijnego w Rzeczypospolitej Polskiej, którą mam zaszczyt referować, dotyczy Tatarów polskich, historycznie litewskimi zwanych, stanowiących niewielką stosunkowo część wielkiego świata muzułmańskiego. Już w XIV wieku poczęli napływać do W. Ks. Litewskiego Tatarzy, pochodzący z Kipczaku, z nad Donu, z Krymu, częściowo dobrowolni wychodźcy, częściowo jeńcy wojenni. Osiedlani byli na roli, częściowo w miastach; zrównani w prawach z ludnością tubylczą, podlegali i obowiązkom narówni z tą ludnością, przedewszystkiem obowiązkowi orężnemu w obronie granic nowej ojczyzny. Dla tego celu Tatarzy mieli własną organizację wojskową, która wystawiała w potrzebie siłę zbrojną, odpowiadającą ich liczebności; zaciągali się również do oddziałów lekkiej jazdy tatarskiej, będącej na stałym żołdzie Rzeczypospolitej. Chorągwie tatarskie, stanowiące kwiat rycerstwa tatarskiego, mają piękne karty w naszej historji. Złożyły one dowody wielkiego męstwa, wytrwałości i poświęcenia w służbie Rzeczypospolitej. Grunwald, Kircholm, Wiedeń, oto pola bitew, gdzie się lała nietylko krew polska, ruska i litewska, ale także i tatarska. Wiek XVI to okres największego rozkwitu tatarszczyzny; liczba Tatarów wynosiła kilkadziesiąt tysięcy; składali się oni z elementu osiadłego na roli, zrównanego w prawach ze szlachtą, i elementu miejskiego, zajmującego się narówni z ludnością tubylczą handlem, rzemiosłem, uprawą warzyw i t.d. Już wtedy skupiali się głównie w tych miejscowościach, w których znajdują się i obecnie największe ich skupienia, a więc w Wilnie i Wileńszczyźnie, Nowogródzkiem, Lidzkiem, Brzeskiem i innych. Żyjąc pomiędzy ludnością obcoplemienną, stracili Tatarzy wiele cech sobie właściwych. Przyswoili sobie kulturę polską, przestali niemal różnić się pod względem języka, obyczajów, ubiorów i t. p. od reszty ludności. Zachowali jednak bardzo wyraźnie odrębność wyznaniową, co ułatwiło im w znacznej mierze zachować poczucie odrębności narodowej. Język ojczysty utracili Tatarzy stosunkowo prędko, gdyż odcięci od masy swych współbraci i grupami osadzeni wśród ludności miejscowej, żenili się bardzo często z chrześcijankami, nieznającemi ich języka; wreszcie językiem liturgicznym, modlitewnym był język arabski, przez co Tatarzy byli pozbawieni jednego z najważniejszych czynników kultywowania mowy ojczystej. Nietylko w dniach wolności Rzeczypospolitej wykazywali dla niej Tatarzy swe synowskie uczucia, zachowali je w okresie również niewoli, w okresie walk z najeźdźcą, wydając z pomiędzy siebie szereg ludzi, których nazwiska jaśnieją blaskiem poświęcenia i bohaterstwa na kartach historji Rzplitej Polskiej. Także przy tworzeniu zrębów zmartwychwstałej państwowości polskiej nie zabrakło twórczych umysłów z pośród społeczeństwa tatarskiego, które dały i dają dotąd poważny wkład do pracy obronnej i organizacyjno-państwowej. Z kolei państwowość polska nie zaniedbuje swych obowiązków względem wiernych swych obywateli Tatarów i realizuje je w myśl starej tradycji polskiej zapewnienia swobody religijnej i tolerancji wyznaniowej swym obywatelom. Parę słów o obecnym stanie posiadania ludnościowym i kulturalnym ludności tatarskiej. Mamy jej w kraju około 6 tysięcy, rozsianej, z małemi wyjątkami, małemi grupami w 20 powiatach przeważnie 4 województw północno-wschodnich. Tak jak w przeszłości żyją Tatarzy w największej harmonji z ludnością tubylczą, przyjmując jej język, obyczaje, kulturę, zachowując jednocześnie odrębną religję, swą narodowość i silną tradycję historyczną. Pod względem organizacyjnym ludność tatarska czyni szybkie postępy, zarówno w dziedzinie religijnej, jak i kulturalno-społecznej. Zorganizowanych jest 19 gmin wyznaniowych, których przedstawiciele w r. 1925 na Wszechpolskim Zjeździe Muzułmańskim w Wilnie ogłosili autokefalję Związku Muzułmańskiego Rzplitej Polskiej. Na tym samym zjeździe wybrany został dr. Jakób Szynkiewicz Muftim, tj. głównym zwierzchnikiem Związku Religijnego Muzułmańskiego w Polsce. W dziedzinie kulturalno-społecznej Tatarzy posiadają liczne organizacje, z których największa »Związek kulturalno-oświatowy Tatarów R.P.« objął teren całej Polski i przyczynił się do podniesienia kulturalnego ludności tatarskiej oraz kultywowania pamiątek jej przeszłości. Aczkolwiek Tatarzy polscy nigdy nie zrywali zupełnie węzłów z ludami muzułmańskiemi, to związki te ożywiły się

Prawo 328, 2019

(C) for this edition by CNS 
jedynie kilka poprawek zawartych w druku senackim $n r 22^{53}$, które miały głównie charakter formalnoprawny ${ }^{54}$.

Pod głosowanie poddano poprawki komisji wymienione w druku senackim nr 22. Jednak przed głosowaniem dodatkową poprawkę, która została odrzuco-

w XX wieku jeszcze silniej, co się najdobitniej przejawiło w udziale polskich Tatarów w walkach o niepodległość Krymu i Azerbajdżanu. W miarę postępów organizacyjnych ludności muzułmańskiej coraz bardziej nagląca stawała się potrzeba uregulowania położenia prawno-religijnego tej ludności w oparciu o ustawę polską, dotychczasowe bowiem przepisy dawnego państwa rosyjskiego, zawarte w par. par. 1342-1415 tomu 11 części I Zbioru Praw — wystarczyć nie mogły. Powstał projekt rządowy ustawy o stosunku Państwa do Muzułmańskiego Związku Religijnego Rzeczypospolitej Polskiej, opracowany po porozumieniu z prawnym reprezentantem wyznania muzułmańskiego, Muftim dr. J. Szynkiewiczem, zgodnie z brzmieniem art. 115 Konstytucji. Projekt ten, złożony Izbom Ustawodawczym, przyjęty został przez Sejm bez zmian i stał się przedmiotem obrad Komisji Prawniczej Senatu na posiedzeniach w dniu 18 i 27 lutego r. b. Uwzględnia on w szerokim zakresie zarówno potrzeby wyznania muzułmańskiego, zapewniając pełną wolność rządzenia się w życiu wewnętrznem, jak również zapewnia możność ingerencji Państwa w sprawy Związku. Uniezależnia się przytem całkowicie pod względem religijnym od obcokrajowych władz, nie zrywając jednocześnie łączności religijnej wewnętrznej ze związkami religijnemi muzułmańskiemi zagranicznemi. Powoływanie władz duchownych Związku następuje w drodze wyboru. Zasada ta jest konsekwentnie przeprowadzana w stosunku do władz od najniższych - Muezzina, Imama, do najwyższych - Muftiego, który sprawuje zwierzchnią władzę w Związku i którego stanowisko jest dożywotnie. Siedzibą Muftiego oraz pomocniczego Najwyższego Kolegjum Muzułmańskiego jest Wilno, centralny punkt rozsiedlenia ludności muzułmańskiej, jak w przeszłości tak i obecnie. Duchowni muzułmańscy korzystają z uprawnień i przywilejów analogicznie do innych wyznań. Majątek nieruchomy, budynki kościelne, dobra i prawa majątkowe, których dochód służy wyłącznie celom kultu religijnego, korzystają z ulg i przywilejów, z których korzystają inne związki religijne"; zob. Sprawozdanie stenograficzne Senatu Rzeczypospolitej Polskiej IV Kadencji z 7 posiedzenia w dniu 6 marca 1936 roku, s. 3-6.

53 W art. 3 zastąpiono wyraz: ,religijnemi potrzebami” wyrazem: ,potrzebami religijnemi”, w art. 4 ust. 1 wyrazy: ,wobec innych kościołów i związków religijnych” zastąpiono wyrazami: „wobec kościołów i innych związków religijnych”, w art. 9 w rocie przysięgi w zdaniach pierwszem i drugiem wyraz ,sprawię" zastąpiono wyrazami „będę czuwał”, w art. 10 ust. 2 w zdaniu pierwszym wyraz „,zawczasu” skreślono, w art. $11 \mathrm{w}$ wierszu trzecim wyraz „swego” skreślono, w art. 18 w zdaniu pierwszym wyrazy „wojewoda właściwy ze względu na położenie danej gminy” zastąpiono wyrazami „właściwy wojewoda”, w art. 20 ust. 1 w zdaniu pierwszym wyrazy „terytorialnie” $\mathrm{i}$,odpowiednich” skreślono, w art. 23 w zdaniu pierwszym wyrazy „piastowanie godności...prawa wyborczego" zastąpiono wyrazami ,piastowanie godności, stanowisk i urzędów zarówno duchowych, jak i świeckich, jako też wszelkie korzystanie z biernego i czynnego prawa wyborczego w Muzułmańskim Związku Religijnym w Rzeczypospolitej Polskiej”, w art. 25 wyrazy „czynów karalnych, pochodzących” zastąpiono wyrazami „czynu karalnego, pochodzącego”, w art. 31 ust. 1 w zdaniu pierwszym i w ust. 3 wyraz „terytorialnie” skreślono, w art. 42 i 45 wyraz ,powszechnie” skreślono; zob. Sprawozdanie Komisji Prawniczej o projekcie ustawy o stosunku Państwa do Muzułmańskiego Związku Religijnego w Rzeczypospolitej Polskiej, uchwalonym przez Sejm w dniu 7 lutego 1936 roku, druk Senatu nr 22 z 1936 r.

54 Sprawozdanie stenograficzne Senatu Rzeczypospolitej Polskiej IV Kadencji z 7 posiedzenia w dniu 6 marca 1936 roku, s. 6.

Prawo 328, 2019

(C) for this edition by CNS 
na w głosowaniu, zgłosił jeden z senatorów ${ }^{55}$. Natomiast projekt ustawy wraz z poprawkami Komisji Prawniczej został uchwalony ${ }^{56}$. Następnie projekt trafił ponownie do sejmowej Komisji Oświatowej, która rozważyła zmiany Senatu na posiedzeniu w dniu 13 marca 1936 roku, przyjmując większość tych zmian ${ }^{57}$. Na 21 posiedzeniu Sejmu w dniu 17 marca 1936 roku B. Pimonow przedstawił sprawozdanie Komisji Oświatowej o zmianach wprowadzonych przez Senat do uchwalonego przez Sejm w dniu 7 lutego 1936 roku projektu ustawy o stosunku Państwa do Muzułmańskiego Związku Religijnego w Rzeczypospolitej Polskiej.

Następnie przystąpiono do głosowania. Najpierw głosowaniu poddano zmiany wprowadzone przez Senat zaakceptowane przez Komisję Oświatową. Poprawki te zostały przez Sejm przyjęte wymaganą większością trzech piątych, zgodnie z art. 53 Konstytucji kwietniowej i art. 83 regulaminu Sejmu. Natomiast zmiany Senatu, co do których Komisja Oświatowa wypowiedziała się negatywnie, zostały przez Sejm odrzucone większością trzech piątych głosów ${ }^{58}$.

Ostatecznie projekt ustawy o stosunku Państwa do Muzułmańskiego Związku Religijnego w Rzeczypospolitej Polskiej po dokonanych zmianach w parlamencie wszedł w życie z dniem ogłoszenia, czyli 24 kwietnia 1936 roku, jako ustawa z dnia 21 kwietnia 1936 roku o stosunku Państwa do Muzułmańskiego Związku Religijnego w Rzeczypospolitej Polskiej ${ }^{59}$.

Warto zaznaczyć, że ustawa muzułmańska pod względem konstrukcji prawnej i ogólnych założeń zbliżona jest do ustawy o stosunku Państwa do Karaimskiego Związku Religijnego w Rzeczypospolitej Polskiej ${ }^{60}$. Obydwie ustawy równocześnie trafiły do Sejmu oraz zostały uchwalone i ogłoszone tego samego dnia ${ }^{61}$.

55 Poprawka została zgłoszona przez senatora S. Siedleckiego, który zgłosił jedną poprawkę do art. 34. Zamiast słów „Podczas nabożeństw w piątki każdego tygodnia, oraz w dnie uroczystych świąt, duchowni muzułmańscy odmawiać będą modlitwy za pomyślność Rzeczypospolitej itd.” proponował wstawić słowa „Podczas nabożeństwa duchowni muzułmańscy odmawiać będą modlitwy za pomyślność Rzeczypospolitej itd.”; zob. Sprawozdanie stenograficzne Senatu Rzeczypospolitej Polskiej IV Kadencji z 7 posiedzenia w dniu 6 marca 1936 roku, s. 7.

56 Sprawozdanie stenograficzne Senatu Rzeczypospolitej Polskiej IV Kadencji z 7 posiedzenia w dniu 6 marca 1936 roku, s. 8.

57 Sprawozdanie Komisji Oświatowej o zmianach wprowadzonych przez Senat do uchwalonego przez Sejm w dniu 7 lutego 1936 roku projektu ustawy o stosunku Państwa do Muzułmańskiego Związku Religijnego w Rzeczypospolitej Polskiej, druk Sejmu nr 98 z 1936 r.; Komisja Oświatowa przyjęła zmiany senackiej Komisji Prawniczej za wyjątkiem zmian w art. 9 i 10.

58 Sprawozdanie stenograficzne Sejmu Rzeczypospolitej Polskiej IV Kadencji z 21 posiedzenia w dniu 17 marca 1936 r., s. 44-45.

59 Dz.U. z 1936 r. Nr 30, poz. 240.

60 Dz.U. z 1936 r. Nr 30, poz. 241.

61 Szerzej o ustawie o stosunku Państwa do Karaimskiego Związku Religijnego w Rzeczypospolitej Polskiej zob. m.in. J. Sawicki, op. cit., s. 198-208; U. Wróblewska, Sytuacja prawna Karaimów w Drugiej Rzeczypospolitej Polskiej w świetle aktów ustawodawczych, [w:] Państwo-religia. Instytucje państwowe i obywatele wobec religii w Europie Środkowo-Wschodniej w XX wieku, red. J. Durka, Kalisz 2014, s. 129-148; S. Dzięciołowski, op. cit.; Ł. Baszak, op. cit., s. 127-144 oraz cyt. tam literatura. 
Celem niniejszej pracy nie jest szczegółowa analiza samej treści ustawy ${ }^{62}$. Niemniej warto zwrócić uwagę na kilka najważniejszych kwestii. Ustawa muzułmańska zawierała postanowienia dotyczące ustroju wewnętrznego Muzułmańskiego Związku Religijnego, składu i kompetencji jego organów (art. 1, 3-7, 8 ust. 1 i 2, 10 ust. 1 i 3, 12 ust. 1, 13, 17, 18 i 36), postanowienia stanowiące treść nadzoru państwowego nad tym związkiem religijnym, normujące stanowisko tego związku religijnego w państwie i uprawnienia władz państwowych w stosunku do niego (art. 2, 6, 7, 8 ust. 3, 9, 10 ust. 2, 11, 12 ust. 2, 14, 15, 17-21, 23, 25-27, 29-31, 34, 35, 37-47), a także kilka cause mixtae, jak sądownictwo w sprawach małżeńskich, nauka religii muzułmańskiej w szkołach i zakładanie szkół duchownych (art. 16, 22, 28, 32, 33) ${ }^{63}$.

W art. 1 stwierdzono niezależność związku od jakichkolwiek władz duchownych i świeckich, który pozostaje w łączności religijno-moralnej ze związkami religijnymi muzułmańskimi zagranicznymi ${ }^{64}$. Zgodnie z art. $2^{65}$ Muzułmański Związek Religijny zaliczono do związków religijnych prawnie uznanych w myśl art. 115 Konstytucji marcowej ${ }^{66}$. Podkreślono łączność pomiędzy ustawą a statutem regulującym życie wewnętrzne związku ${ }^{67}$.

Ustawa regulowała również ogólne zarysy ustroju wewnętrznego. Zgodnie z art. 3 ustawy ${ }^{68}$ zwierzchnią władzą Muzułmańskiego Związku Wyznaniowego był „Mufti Muzułmański w Rzeczypospolitej Polskiej ${ }^{69}$ z pomocą Najwyższe-

62 Szerzej na temat postanowień ustawy o stosunku Państwa do Muzułmańskiego Związku Religijnego w Rzeczypospolitej Polskiej zob. J. Sawicki, op. cit., s. 184-197; P. Wiązek Samorządność Muzułmanów w Polsce w świetle przepisów ustawy z dnia 21 kwietnia 1936 roku o stosunku Państwa do Muzutmańskiego Związku Religijnego w Rzeczypospolitej Polskiej, [w:] Samorząd i samorzadność w przeszłości i teraźniejszości, red. M.J. Ptak, Wrocław 2013, s. 145-156.

63 J. Sawicki, op. cit., s. 184-185, 195.

64 Art. 1. „Wyznawcy Islamu na obszarze Rzeczypospolitej Polskiej, pozostając w łączności religijno-moralnej ze związkami religijnemi muzułmańskiemi zagranicznemi, tworzą Muzułmański Związek Religijny w Rzeczypospolitej Polskiej, niezależny od jakichkolwiek obcokrajowych władz duchownych i świeckich".

65 Art. 2. „Muzułmański Związek Religijny w Rzeczypospolitej Polskiej korzysta w swem życiu wewnętrznem z pełnej wolności rządzenia się, w ramach praw obowiązujących, przepisami swego Statutu (Ustawy Wewnętrznej), uznanego przez Państwo w drodze rozporządzenia Rady Ministrów. Statut Muzułmańskiego Związku Religijnego w Rzeczypospolitej Polskiej stanowi wraz z ustawą niniejszą podstawę prawną organizacji tego Związku”.

66 Art. 115 Konstytucji marcowej: „Kościoły mniejszości religijnych i inne prawnie uznane związki religijne rządzą się same własnymi ustawami, których uznania Państwo nie odmówi, o ile nie zwierają postanowień sprzecznych z prawem. Stosunek Państwa do Kościołów i wyznań będzie ustalony w drodze ustawowej po porozumieniu się z ich prawnym reprezentacjami”.

67 Dz.U. z 1936 r. Nr 72, poz. 1175.

68 Art. 3. „Zwierzchnią władzę w Muzułmańskim Związku Religijnym w Rzeczypospolitej Polskiej oraz nadzór nad wykonywaniem obowiązków przez duchowieństwo i pieczę nad potrzebami religijnemi muzułman sprawuje Mufti Muzułmański w Rzeczypospolitej Polskiej z pomocą Najwyższego Kolegjum Muzułmańskiego”.

69 Na temat wyboru muftiego z uwzględnieniem zasad Konstytucji z 1997 roku zob. P. Borecki, Obsada godności Muftiego Muzułmańskiego..., s. 7-28.

Prawo 328, 2019

(C) for this edition by CNS 
go Kolegium Muzułmańskiego". Poza tym organem związku był Wszechpolski Kongres Muzułmański. Z kolei na czele gminy wyznaniowej stał imam, którego zastępcą i pomocnikiem był muezzin ${ }^{70}$.

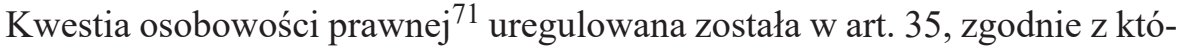
rym Muzułmański Związek Religijny jako całość oraz jego poszczególne gminy wyznaniowe były osobami prawnymi mającymi możliwość nabywania, zbywania, obciążania, zarządzania i rozporządzania swoim majątkiem ruchomym i nieruchomym dla swych celów wyznaniowych i dobroczynnych ${ }^{72}$.

W ustawie znalazły się również przepisy dotyczące uprawnień władz państwowych w stosunku do Muzułmańskiego Związku Religijnego. Głównie dotyczyły one zasad wyboru urzędów i funkcjonowania związku. Minister Wyznań Religijnych i Oświecenia Publicznego zatwierdzał listy kandydatów na urząd muftiego oraz członków Najwyższego Kolegium Muzułmańskiego. Z kolei wojewodom przysługiwało prawo sprzeciwu wobec kandydatów na urząd imamów, a także żądanie usunięcia funkcjonariuszy duchownych prowadzących działalność sprzeczną z interesami państwa. Powstałe w tych sprawach rozbieżności ostatecznie rozstrzygał Minister Wyznań Religijnych i Oświecenia Publicznego. Poza tym władze państwowe wpływały na zarząd majątkiem wyznania. Wszystkie czynności prawne mające na celu zbycie, obciążenie lub zmianę przeznaczenia majątku nieruchomego wymagały dla swej ważności zgody właściwego wojewody (art. 37). Natomiast wszelkie szczegółowe przepisy i regulaminy wydane przez władze wyznaniowe w celu wykonania postanowień statutu wewnętrznego, co do których nie przewidziano uprzedniego ich uzgadniania z rządem, musiały uzyskać akceptację ministra wyznań pod względem ich zgodności z obowiązującym prawem, ustawą i statutem związku (art. 47) ${ }^{73}$.

Poza tym w ustawie znalazły miejsce jeszcze między innymi przepisy normujące sprawę sądownictwa duchownego (art. 16), związane z nauką religii muzułmańskiej w szkołach (art. 32) i zakładaniem szkół duchownych (art. 33) ${ }^{74}$.

Uroczystego wręczenia muftiemu J. Szynkiewiczowi Dziennika Ustaw Rzeczypospolitej Polskiej, w którym ogłoszono ustawę o stosunku Państwa do Muzułmańskiego Związku Religijnego, dokonał w dniu 26 kwietnia 1936 roku minister wyznań religijnych i oświecenia publicznego Wojciech Świętosławski.

70 Szerzej J. Sawicki, op. cit., s. 185-190.

71 Kwestię osobowości prawnej związków wyznaniowych w II RP szeroko omawia J. Osuchowski, op. cit., s. 407-459.

72 Dz.U. z 1936 r. Nr 30, poz. 240.

73 K. Krasowski, op. cit., s. 201-202; szerzej o postanowieniach stanowiących treść nadzoru państwowego nad Muzułmańskim Związkiem Religijnym zob. J. Sawicki, op. cit., s. 190-195.

74 Szerzej J. Sawicki, op. cit., s. 195-197. 
Uroczystość odbyła się w sali konferencyjnej wileńskiego urzędu wojewódzkiego i dotyczyła również Karaimskiego Związku Religijnego ${ }^{75}$.

Kończącym etapem regulującym położenie prawne Muzułmańskiego Związku Religijnego w II Rzeczypospolitej było rozporządzenie Rady Ministrów z dnia 26 sierpnia 1936 roku o uznaniu Statutu Muzułmańskiego Związku Religijnego w Rzeczypospolitej Polskiej wydane na podstawie art. 2 ustawy o stosunku Państwa do Muzułmańskiego Związku Religijnego w Rzeczypospolitej Polskiej ${ }^{76}$.

Analizując przepisy ustawy o stosunku Państwa do Muzułmańskiego Związku Religijnego, wydaje się, że zarzut Komisji Prawniczej o dokonaniu częściowej recepcji przepisów rosyjskich miał swoje uzasadnienie. Widoczne jest to przy przepisach określających ustrój wewnętrzny związku, z silną władzą muftiego nieskrępowanego opiniami organów doradczych ${ }^{77}$.

\section{Zakończenie}

W okresie II Rzeczypospolitej Muzułmański Związek Religijny był jednym z sześciu związków mniejszości wyznaniowych, którego sytuacja prawna została uregulowana. Oprócz Muzułmańskiego Związku Religijnego uregulowano sytuację prawną Żydowskiego Związku Religijnego ${ }^{78}$, Wschodniego Kościoła Staroobrzędowego nieposiadającego hierarchii duchownej ${ }^{79}$, Karaimskiego Związku Religij-

75 Uroczystość wręczenia odznaczeń najwyższym duchownym: karaimskiemu i muzutmańskiemu, 1. Przemówienie Ministra Wyznań Religijnych i Oświecenia Publicznego w czasie dekoracji Hachana Karaimskiego, 2. Odpowiedź J. E. Hachana Karaimów na powyższe przemówienie, „Myśl Karaimska” 11, 1935-1936, z. 11, s. 123-125, http://www.jazyszlar.karaimi.org/index. php?m=7\&p=341 (dostęp: 10 grudnia 2019).

76 Zgodnie z art. 2 ustawy o stosunku Państwa do Muzułmańskiego Związku Religijnego w Rzeczypospolitej Polskiej Rada Ministrów wydała rozporządzenie z dnia 26 sierpnia 1936 roku o uznaniu Statutu Muzułmańskiego Związku Religijnego w Rzeczypospolitej Polskiej (Dz.U. z 1936 r. Nr 72, poz. 1175). Statut zawierał 55 paragrafów i stanowił załącznik do rozporządzenia. Zostały w nim określone uprawnienia muftiego, Najwyższego Kolegium Muzułmańskiego, Wszechpolskiego Kongresu, gmin wyznaniowych, a także sprawy związane z nauczaniem religii, odprawianiem uroczystych modłów w święta itd. J. Sawicki zarzucał, że postanowienia ustawy są zbyt szerokie, jeśli chodzi o ustrój władz i organów, ich kompetencje i sposób działania, ponieważ takie dokładne postanowienia powinny znaleźć się w statucie wewnętrznym związku, a nie w ustawie; zob. J. Sawicki, op. cit., s. 197.

77 J. Sobczak, Położenie prawne tatarskich..., s. 520; K. Krasowski, op. cit., s. 202.

78 Rozporządzenie Ministra Wyznań Religijnych i Oświecenia Publicznego z dnia 5 kwietnia 1928 roku (Dz.U. z 1928 r. Nr 52, poz. 500).

79 Rozporządzenie Prezydenta Rzeczypospolitej Polskiej z dnia 22 marca 1928 roku o stosunku państwa do Wschodniego Kościoła Staroobrzędowego, nieposiadającego hierarchii duchownej (Dz.U. z 1928 r. Nr 38, poz. 363).

Prawo 328, 2019

(C) for this edition by CNS 
nego ${ }^{80}$, Kościoła Ewangelicko-Augsburskiego ${ }^{81}$ oraz Kościoła Prawosławnego ${ }^{82}$. W stosunku do karaimów Kościoła Ewangelicko-Augsburskiego oraz Kościoła Prawosławnego tak jak w przypadku muzułmanów wydano statuty wewnętrzne ${ }^{83}$. Status prawny Muzułmańskiego Związku Religijnego w okresie Polskiej Rzeczypospolitej Ludowej i III Rzeczypospolitej, podobnie jak Wschodniego Kościoła Staroobrzędowego nieposiadającego hierarchii duchownej i Karaimskiego Związku Religijnego, formalnie określały i nadal określają akty normatywne z okresu II Rzeczypospolitej. Zatem ustawa o stosunku Państwa do Muzułmańskiego Związku Religijnego wciąż obowiązuje, mimo że ustanowiona została w warunkach zasadniczo odmiennego systemu relacji między państwem a związkami wyznaniowymi, czyli w warunkach systemu zwierzchnictwa konfesyjnego państwa nad wyznaniami. Ustawa ta jest w wielu punktach już nieaktualna, chociażby ze względu na zmianę granic po drugiej wojnie światowej ${ }^{84}$. Niewątpliwie ustawa o stosunku Państwa do Muzułmańskiego Związku Religijnego z 1936 roku wymaga zmian lub uchylenia i zastąpienia jej nową ustawą, dostosowaną do wymogów współczesnych. W razie podjęcia takich działań należałoby tego dokonać zgodnie z postanowieniami art. 25 ust. 5 Konstytucji RP z 1997 roku, czyli z zachowaniem form konsensualnych polegających na zawarciu odpowiedniej umowy pomiędzy Radą Ministrów a Muzułmańskim Związkiem Wyznaniowym $^{85}$. Warto jeszcze dodać, że inaczej wygląda sprawa ze statutem Muzułmańskiego Związku Wyznaniowego z 1936 roku, który został zastąpiony w okresie PRL statutem z dnia 12 stycznia 1969 roku $^{86}$, a następnie statutem $\mathrm{z}$ dnia 28 lutego 2009 roku. Obydwa statuty nie zostały poddane zgodnej z ustawą procedurze ${ }^{87}$.

80 Ustawa o stosunku Państwa do Karaimskiego Związku Religijnego w Rzeczypospolitej Polskiej z dnia 21 kwietnia 1936 r. (Dz.U. z 1936 r. Nr 30, poz. 241).

81 Dekret Prezydenta Rzeczypospolitej Polskiej z dnia 25 listopada 1936 roku o stosunku Państwa do Kościoła Ewangelicko-Augsburskiego w Rzeczypospolitej Polskiej (Dz.U. z 1936 r. Nr 88, poz. 613).

82 Dekret prezydenta Rzeczypospolitej z dnia 18 listopada 1938 roku o stosunku Państwa do Polskiego Autokefalicznego Kościoła Prawosławnego (Dz.U. z 1938 r. Nr 88, poz. 539).

83 J. Osuchowski, op. cit., s. 226-235.

84 Szczegółowo o postanowieniach ustawy o stosunku Państwa do Muzułmańskiego Związku Religijnego z 1936 r. niezgodnych z Konstytucją z 2 kwietnia 1997 roku; zob. P. Borecki, Położenie prawne wyznawców islamu w Polsce, „Państwo i Prawo” 63, 2008, z. 1, s. 78-83, P. Wiązek, op. cit., s. $154-155$.

85 P. Borecki, Prawodawstwo wyznaniowe z okresu II Rzeczypospolitej we współczesnym polskim systemie prawnym, „Studia Prawa Publicznego” 2014, nr 4 (8) s. 79; w pracy tej autor szerzej porusza problem niekonstytucyjności i anachroniczności między innymi przepisów ustawy o stosunku Państwa do Muzułmańskiego Związku Religijnego z 1936 roku.

86 Szerzej W. Wysoczański, Prawo wewnętrzne Kościołów i wyznań nierzymskokatolickich w PRL, Warszawa 1971, s. 270-278; W. Wysoczański, M. Pietrzak, op. cit., s. 388-395; R. Kaczmarczyk, Status prawny i faktyczny muzułmańskich związów wyznaniowych $w$ Polsce, „Studia z Prawa Wyznaniowego" 19, 2016, s. 266 -267.

87 Statut ten stanowi podstawę organizacji gmin muzułmańskich, mimo że nie został poddany zgodnej z ustawą procedurze, podobnie zresztą jak statut z 1969 roku; szerzej R. Kaczmarczyk, op. cit., s. 267-269. 


\section{Bibliografia}

\section{Źródła prawa}

Dekret Prezydenta Rzeczypospolitej Polskiej z dnia 25 listopada 1936 roku o stosunku Państwa do Kościoła Ewangelicko-Augsburskiego w Rzeczypospolitej Polskiej (Dz.U. z 1936 r. Nr 88, poz. 613).

Dekret Prezydenta Rzeczypospolitej z dnia 18 listopada 1938 roku o stosunku Państwa do Polskiego Autokefalicznego Kościoła Prawosławnego (Dz.U. z 1938 r. Nr 88, poz. 597).

Rozporządzenie ministra Wyznań Religijnych i Oświecenia Publicznego z dnia 5 czerwca 1928 roku (Dz.U. z 1928 r. Nr 52, poz. 500).

Rozporządzenie Prezydenta Rzeczpospolitej Polskiej z dnia 22 marca 1928 roku o stosunku Państwa do Wschodniego Kościoła Staroobrzędowego, nieposiadającego hierarchii duchownej (Dz.U. z 1928 r. Nr 38, poz. 363).

Rozporządzenie Rady Ministrów z dnia 26 sierpnia 1936 roku o uznaniu Statutu Muzułmańskiego Związku Religijnego w Rzeczypospolitej Polskiej (Dz.U. z 1936 r. Nr 72, poz. 1175).

Rządowy projekt ustawy o stosunku Państwa do Muzułmańskiego Związku Religijnego w Rzeczypospolitej Polskiej, druk Sejmu nr 24 z 1936 r.

Sprawozdanie Komisji Oświatowej o rządowym projekcie ustawy o stosunku Państwa do Karaimskiego Związku Religijnego w Rzeczypospolitej Polskiej, druk Sejmu nr 57 z 1936 r.

Sprawozdanie Komisji Oświatowej o zmianach wprowadzonych przez Senat do uchwalonego przez Sejm w dniu 7 lutego 1936 roku projektu ustawy o stosunku Państwa do Muzułmańskiego Związku Religijnego w Rzeczypospolitej Polskiej, druk Sejmu nr 98 z 1936 r.

Sprawozdanie Komisji Prawniczej o projekcie ustawy o stosunku Państwa do Muzułmańskiego Związku Religijnego w Rzeczypospolitej Polskiej, uchwalonym przez Sejm w dniu 7 lutego 1936 roku, druk Senatu nr 22 z 1936 r.

Sprawozdanie stenograficzne Sejmu Rzeczypospolitej Polskiej IV kadencji z 9 posiedzenia w dniu 7 lutego 1936 roku.

Sprawozdanie stenograficzne Senatu Rzeczypospolitej Polskiej IV kadencji z 7 posiedzenia w dniu 6 marca 1936 roku.

Sprawozdanie stenograficzne Sejmu Rzeczypospolitej Polskiej IV kadencji z 21 posiedzenia w dniu 17 marca 1936 roku.

Ustawa o stosunku Państwa do Muzułmańskiego Związku Religijnego w Rzeczypospolitej Polskiej z dnia 21 kwietnia 1936 roku (Dz.U. z 1936 r. Nr 30, poz. 240).

Ustawa o stosunku Państwa do Karaimskiego Związku Religijnego z dnia 21 kwietnia 1936 roku (Dz.U. z 1936 r. Nr 30, poz. 241).

Ustawa konstytucyjna z dnia 17 marca 1921 roku (Dz.U. RP z 1921 r. Nr 44, poz. 267).

Ustawa konstytucyjna z dnia 23 kwietnia 1935 roku (Dz.U. z 1936 r. Nr 30, poz. 277).

\section{Internet}

Dzięciołowski S., Aneks - Z dziejów parlamentaryzmu polskiego. Ustawy o muzulmańskim i karaimskim zwiazkach wyznaniowych, ,Kronika Sejmowa” 2001, nr 14 (495), s. 9, http://archive.today/ OT15A (dostęp: 16 czerwca 2019).

Muzułmański Związek Religijny w Rzeczypospolitej Polskiej, Historia MZR w RP, http://mzr.pl/historia-mzr-w-rp/ (dostęp: 16 czerwca 2019).

Uroczystość wręczenia odznaczeń najwyższym duchownym: karaimskiemu i muzulmańskiemu, 1. Przemówie-nie Ministra Wyznań Religijnych i Oświecenia Publicznego w czasie dekoracji

Prawo 328, 2019

(C) for this edition by CNS 
Hachana Karaimskiego, 2. Odpowiedź J. E. Hachana Karaimów na powyższe przemówienie, „Myśl Karaimska” 11, 1935-1936, z. 11, s. 123-125, http://www.jazyszlar.karaimi.org/index. php?m=7\&p=341 (dostęp: 10 grudnia 2019).

\section{Literatura}

Achmatowicz A., Zarys stanu prawnego wyznania muzułmańskiego w b. Rosji $i$ współczesnej Polsce, „Rocznik Tatarski” 1, 1932.

Baszak Ł., Prace legislacyjne nad ustawa o stosunku Państwa do Karaimskiego Zwiąku Religijnego w Rzeczypospolitej Polskiej, „Folia Iuridica Universitatis Wratislaviensis” 4, 2015, nr 1, s. 127-144.

Borawski P., O przynależności Tatarów hospodarskich do stanu szlacheckiego, s. 345-358.

Borawski P., Położenie prawne Tatarów Wielkiego Księstwa Litewskiego, „Lituano-Slavica Posnaniensia" 2, 1987, s. 187-212.

Borawski P., Tatarzy dawnej Rzeczypospolitej, Warszawa 1986.

Borawski P., Tatarzy-ziemianie w dobrach Radziwittów (XVI-XVIII w.), „Przegląd Historyczny” 82, 1991, nr 1, s. 33-49.

Borecki P., Obsada godności Muftiego Muzutmańskiego Związku Religijnego a zasady Konstytucji RP, „Studia Prawnicze” 2018, nr 1, s. 9-29.

Borecki P., Prawodawstwo wyznaniowe z okresu II Rzeczypospolitej we współczesnym polskim systemie prawnym, „Studia Prawa Publicznego” 2014, nr 4 (8), s. 61-81.

Grelewski S., Wyznania protestanckie i sekty religijne w Polsce wspótczesnej. Zarys stanu prawnego wyznań religijnych w Polsce, Sandomierz 1935.

Kaczmarczyk R., Status prawny i faktyczny muzulmańskich związków wyznaniowych w Polsce, „Studia z Prawa Wyznaniowego" 19, 2016, s. 263-287.

Komarnicki W., Polskie prawo polityczne (geneza i system), Warszawa 1922.

Krasowski K., Zwiąki wyznaniowe w II Rzeczypospolitej. Studium historycznoprawne, Warszawa-Poznań 1988.

Krukowski J., Polskie prawo wyznaniowe, Warszawa 2008.

Leszczyński P.A., Centralna administracja wyznaniowa w II RP. Ministerstwo Wyznań Religijnych i Oświecenia Publicznego, Warszawa 2006.

Mezglewski A., Misztal H., Stanisz P., Prawo wyznaniowe, Warszawa 2011.

Misztal H., Polskie prawo wyznaniowe, Lublin 1996.

Miśkiewicz A., Mniejszość tatarska w Polsce w latach 1918-1939, „Przegląd Historyczny” 77, 1986, nr 2, s. 241-267.

Osuchowski J., Prawo wyznaniowe Rzeczypospolitej Polskiej 1918-1939, Warszawa 1967.

Piekarski S., Wyznania religijne w Polsce, Warszawa 1927.

Pietrzak M., Prawo wyznaniowe, Warszawa 2013.

Sawicki J., Studia nad położeniem prawnym mniejszości religijnych $w$ państwie polskim, Warszawa 1937.

Sobczak J., Czy tatarska ludność Litwy należała do stanu szlacheckiego?, „Przegląd Historyczny” 1986, z. 3, s. 467-480.

Sobczak J., Położenie prawne ludności tatarskiej w wielkim Księstwie Litewskim, Warszawa 1984.

Sobczak J., Położenie prawne tatarskich wyznawców islamu w II Rzeczypospolitej, „Przegląd Historyczny" 79, 1988, nr 3, s. 501-520.

Sobczak J., Tatarzy w stużbie Rzeczypospolitej $w$ drugiej połowie XVII i w XVIII w. Studium historycznoprawne, „Czasopismo Prawno-Historyczne” 1987, z. 1, s. 41-70.

Wiązek P., Samorzadność Muzułmanów w Polsce w świetle przepisów ustawy z dnia 21 kwietnia 1936 roku o stosunku Państwa do Muzutmańskiego Zwiazku Religijnego w Rzeczypospolitej Polskiej, [w:] Samorząd i samorządność w przeszłości i teraźniejszości, red. M.J. Ptak, Wrocław 2013.

Prawo 328, 2019

(C) for this edition by CNS 
Wysoczański W., Prawo wewnętrzne Kościołów $i$ wyznań nierzymskokatolickich w PRL, Warszawa 1971.

Wysoczański W., Pietrzak M., Prawo wewnętrzne Kościołów i związków wyznaniowych nierzymskokatolickich w Polsce, Warszawa 1997.

\title{
Legislative work on the Act on the Relations between the State and the Muslim Religious Association in the Republic of Poland
}

\author{
Summary
}

After regaining its independence the Second Polish Republic inherited various legal systems from the partitioning powers. They differed with regard to both legal institutions and legal constructs. This state of affairs hindered the integration of the state and caused a lot of problems in socio-economic relations. This was reflected also in the law dealing with religions. The reborn Polish state had to define the legal status of churches and religious associations, among others.

The author of the article presents the work associated with the regulation of the legal status of the Muslim Religious Association. The Muslims, who were, with few exceptions, Polish Tatars, were a small minority in the Second Polish Republic. Nevertheless, they managed, following more than a decade of consultations with the government, to have the Act adopted, in accordance with Article 115 of the March Constitution. The Constitution was also the basis of the issuance of an ordinance concerning the recognition of the internal statutes of the association.

Keywords: religious law in the Second Polish Republic, associations of religious minorities in the Second Polish Republic, Muslims, Tartars, Islam, Muslim Religious Association, Act of Parliament on the Relations between the State and the Muslim Religious Association

\section{Gesetzgebungsverfahren betreffend das Verhältnis des Staates zu der Muslimischen Glaubensgemeinschaft in der Republik Polen}

\section{Zusammenfassung}

Polen, das die Unabhängigkeit zurückgewonnen hat, hat auch die diversen Rechtssysteme der Teilungsmächte geerbt. Sie unterschieden sich voneinander sowohl im Bereich der Institutionen als auch der rechtlichen Konstruktionen. Dieser Zustand erschwerte die Integration des Staates und führte zu vielen Problemen im Bereich der wirtschaftlich-sozialen Verhältnisse. Widerspiegelt hat sich das auch im Bereich des Staatskirchenrechts. Eine der Aufgaben des wiedergeborenen Staates war unter anderem, den Rechtsstatus der Kirchen und Glaubensgemeinschaften zu bestimmen.

In dem Artikel werden die Arbeiten betreffend die Regulierung des Rechtsstatus der Muslimischen Glaubensgemeinschaft dargestellt. Die Muslime, die mit wenigen Ausnahmen polnische Tataren waren, stellten in der Zweiten Polnischen Republik eine kleine religiöse Minderheit dar. Trotzdem gelang es ihnen, dass ein Gesetz gem. Art. 115 der März-Verfassung nach einigen Jahren 
von Konsultationen mit der Regierung verabschiedet wurde. Es war auch die Grundlage der Verordnung über die Anerkennung der internen Satzung der Gemeinschaft.

Schlüsselworte: Staatskirchenrecht in der Zweiten Polnischen Republik, Glaubensgemeinschaften der religiösen Minderheiten in der Zweiten Polnischen Republik, Muslime, Tataren, Islam, Muslimische Glaubensgemeinschaft, das Gesetz über das Verhältnis des Staates zu der Muslimischen Glaubensgemeinschaft 